\title{
Oocyte activation and preimplantation development of bovine embryos obtained by specific inhibition of cyclin-dependent kinases
}

\author{
[Ativação oocitária e desenvolvimento pré-implantação de embriões bovinos obtidos com o uso de inibidores \\ específicos das quinases dependentes de ciclina] \\ F. Perecin ${ }^{1}$, S.C. Méo ${ }^{2}$, C.L.V. Leal ${ }^{3}$, J.M. Garcia ${ }^{1}$ \\ ${ }^{1}$ Faculdade de Ciências Agrárias e Veterinárias - UNESP \\ Via de Acesso Prof. Paulo Donato Castellane, s/n \\ 14884-900 - Jaboticabal, SP \\ ${ }^{2}$ Instituto de Zootecnia - Nova Odessa, SP \\ ${ }^{3}$ Faculdade de Zootecnia e Engenharia de Alimentos-USP - Pirassununga, SP
}

\begin{abstract}
The efficiency of bohemine and roscovitine in combination with ionomycin on parthenogenetic activation and initial embryonic development of bovine oocytes was studied. Two experiments were performed: in the first, different concentrations $(0,50,75$ or $100 \mu \mathrm{M})$ and different exposure periods $(2,4$ or 6 hours) to bohemine or roscovitine were tested for activation rates of in vitro matured (IVM) bovine oocytes, which were pre-exposed to ionomycin. The best treatments, $75 \mu \mathrm{M}$ bohemine and $50 \mu \mathrm{M}$ roscovitine, both for $6 \mathrm{~h}$, were used in the second experiment, in which IVM bovine oocytes were exposed to ionomycin, followed or not by bohemine or roscovitine treatment, and evaluated for nuclear status, activation rate and blastocyst development were assessed. The combined treatments (ionomycin + cyclin-dependent kinases inhibitors - CDKIs) showed better results for activation rates (77.3\%) and initial embryonic development $(35.2 \%)$ than the single ionomycin treatment $(69.4 \%$ for activation and $21.9 \%$ for development); and also lead to a more uniform activation (nearly $90 \%$ single pronucleus development). The results showed that CDKIs improve the effects of ionomycin on parthenogenetic activation and blastocyst development in bovine oocytes and could help to achieve more efficient activation protocols, increasing the developmental competence of embryos obtained by reproductive biotechniques.
\end{abstract}

Keywords: bovine, artificial activation, bohemine, roscovitine, parthenogenesis

\section{RESUMO}

Realizaram-se dois experimentos para avaliar a eficiência da bohemina e roscovitina associadas à ionomicina para ativação partenogenética e desenvolvimento embrionário inicial de bovinos. No primeiro, foram testadas diferentes concentrações $(0,50,75$ ou $100 \mu \mathrm{M})$ e diferentes tempos de exposição (2, 4 ou 6 horas) à bohemina ou à roscovitina na ativação de oócitos bovinos maturados in vitro (MIV) pré-expostos à ionomicina. Os melhores tratamentos, bohemina $75 \mu \mathrm{M}$ e roscovitina $50 \mu \mathrm{M}$, ambos por seis horas, foram utilizados no segundo experimento, no qual oócitos bovinos MIV foram expostos à ionomicina seguido ou não pelo tratamento com inibidores especificos das quinases dependentes de ciclina (CDKI), e avaliados quanto à configuração nuclear, taxa de ativação e desenvolvimento até blastocisto. Os tratamentos combinados (ionomicina $+C D K I$ ) apresentaram melhor taxa de ativação $(77,3 \%)$ e desenvolvimento embrionário inicial $(35,2 \%)$ do que a ionomicina sozinha $(69,4 \%$ e $21,9 \%$, respectivamente), e também promoveram ativação mais uniforme (aproximadamente $90 \%$ de formação de um pronúcleo). Estes resultados demonstram que os CDKIs potencializam o efeito da ionomicina na

Recebido em 10 de março de 2004

Aceito em 7 de fevereiro de 2007

E-mail: fperecin@fcav.unesp.br

Apoio: FAPESP 
ativação e desenvolvimento embrionário inicial e podem auxiliar na obtenção de protocolos de ativação mais eficientes, aumentando a capacidade de desenvolvimento de embriões produzidos por meio de biotécnicas reprodutivas.

Palavras-chave: bovino, ativação artificial, bohemina, roscovitina, partenogênese

\section{INTRODUCTION}

Bovine oocytes are ovulated in the metaphase II (MII) stage. At this moment, they are unable to start development if not fertilized by a spermatozoon or parthenogenetically activated. Fertilization or parthenogenetic activation restores the ability of the oocyte to progress through the cell cycle (meiosis resumption) by inducing a series of morphological and physiological changes, generically referred as activation (Talmor-Cohen et al., 2002).

The spermatozoon is the natural trigger for oocyte activation. Penetration of a spermatozoon in a MII oocyte leads to a series of cellular and biochemical modifications, such as: intracellular $\mathrm{Ca}^{2+}$ oscillations (Fissore et al., 1992); cortical granule exocytosis (Moses et al., 1995); phosphorylation and dephosphorylation of cell cycle regulating proteins (Lewin, 1990), meiosis resumption, pronuclear formation and cell division.

Oocytes can also be artificially activated. The interest in studying parthenogenetic activation mechanisms has increased due to the development of embryo biotechnologies, such as cloning by nuclear transfer (Cibelli et al., 1998; Wells et al., 1999) and intracytoplasmic sperm injection (ICSI) experiments (Suttner et al., 2000). These procedures require simple and efficient systems to promote oocyte activation. Moreover, the control of bovine oocyte parthenogenetic activation leads to a better understanding of technical and biological factors involved in parthenogenesis and embryonic development. Besides, it generates an adequate model to study some aspects of early embryonic development, such as, the influence of ploidy and imprinted genes on animal development (Solter, 1988).

Many different treatments have already been used in an attempt to mimic the activation induced by the spermatozoon, including physical methods such as electrical pulse (Ozil, 1990) or chemical methods, such as ethanol (Liu et al., 1998), calcium ionophore (Soloy et al, 1997), ionomycin (Susko-Parrish et al., 1994), strontium chloride (Wakayama et al., 1998; Méo et al., 2002; Leal et al., 2003), cycloheximide (Presicce and Yang, 1994; Liu et al., 1998), or 6dimethylaminopurine (6-DMAP) (Susko-Parrish et al., 1994; Loi et al., 1998). These activation treatments can be used either alone or in combination.

The best parthenogenetic activation results have been achieved by the use of intracellular calcium transient inducing agents combined with protein synthesis inhibitors (cycloheximide) or protein phosphorylation inhibitors (6-DMAP). Although cycloheximide and 6-DMAP allow high rates of parthenogenetic activation and development of bovine embryos reconstructed by nuclear transfer to the blastocyst stage, high proportions of advanced pregnancy losses, perinatal death and severe abnormalities in the fetal and neonatal conceptus development (Cibelli et al., 1998; Wells et al., 1999) suggest that these activation protocols may have detrimental effects on embryo development. Cyclohexemide and 6DMAP non-specifically affect several metabolic pathways in the oocyte and may impair further embryonic development (Alberio et al., 2000).

A new family of chemical substances generically called cyclin-dependent kinase inhibitors (CDKIs), which include roscovitine and bohemine, brought new perspectives in the field of oocyte and embryo manipulation, since their use in parthenogenetic activation may help to achieve less deleterious conditions and represent an advance in the efficiency of activation protocols in mammals. The improvement of reproductive biotechnologies results depends on a better understanding of the biological phenomena that are involved throughout the process and also on the reduction of the negative effects that the technique and the in vitro manipulation conditions may have on embryonic and fetal development. 
Thus, this study aims to examine the nuclear status of the oocytes after the activation treatments and compare the activation efficiency (pronuclear formation and embryonic development) of bohemine or roscovitine in combination with ionomycin.

\section{MATERIALS AND METHODS}

In order to evaluate the efficiency of bohemine and roscovitine in combination with ionomycin on parthenogenetic activation and initial embryonic development of bovine oocytes, two experiments were performed.

Antral follicles from bovine ovaries collected from nearby slaughterhouses were aspirated and the follicular fluid transferred to a polystyrene tube. After the end of aspiration, the tube contents were left undisturbed for 15 minutes at $38.5^{\circ} \mathrm{C}$ and $5 \% \mathrm{CO}_{2}$ in air. The sediment was visualized under a stereomicroscope and oocytes with homogeneous cytoplasm and compact cumulus (at least 4 layers of cells) were selected and washed in wash medium [Hepes ${ }^{1}$-buffered TCM-1992, supplemented with $10 \%$ heatinactivated $\left(55^{\circ} \mathrm{C}\right.$ for $\left.30 \mathrm{~min}\right)$ fetal calf serum (FCS), $0.25 \mathrm{mM}$ sodium pyruvate ${ }^{3}$ and $75 \mu \mathrm{g} / \mathrm{mL}$ kanamycin $^{4}$ ] and transferred to maturation medium droplets [sodium bicarbonate ${ }^{5}$-buffered $(2.2 \mathrm{mg} / \mathrm{mL}) \mathrm{TCM}-199$, supplemented with $10 \%$ FCS, $\quad 0.5 \mu \mathrm{g} / \mathrm{mL} \quad \mathrm{FSH}^{6}, \quad 100 \mathrm{UI} / \mathrm{mL}^{\mathrm{hCG}^{7}}$, $1 \mu \mathrm{mg} / \mathrm{mL}$ estradiol $^{8}, 0.25 \mathrm{mM}$ sodium pyruvate and $75 \mu \mathrm{g} / \mathrm{mL}$ kanamycin] (10-20 oocytes $/ 100 \mu \mathrm{L}$ droplet), covered with mineral oil ${ }^{9}$ and cultured at $38.5^{\circ} \mathrm{C}$ and $5 \% \mathrm{CO}_{2}$ in air.

Two hours before the activation treatments, the oocytes were removed from the maturation medium and incubated in calcium-free phosphate-buffered saline (PBS) supplemented with $0.1 \% \mathrm{PVA}^{10}$ (polyvinyl alcohol) and $0.2 \%$ of hyaluronidase ${ }^{11}$ at $38.5^{\circ} \mathrm{C}$ for 5 minutes, followed by gentle pippeting for 3 to 5 minutes to remove the cumulus cells. Denuded oocytes were transferred to a dish with wash medium and those with a healthy appearance and presence of one polar body were selected and designated to the activation treatments. The selected oocytes were returned to maturation droplets and kept under culture conditions until the activation treatments.
Experiment 1 aimed to determine the best concentration and the best exposure time for bohemine $(\mathrm{B}-$ experiment $1 \mathrm{a})$ and roscovitine ${ }^{12}$ ( $\mathrm{R}$ - experiment $1 \mathrm{~b})$. The concentrations of 0,50 , 75 , and $100 \mu \mathrm{M}$ and exposure periods of 2,4 , and 6 hours were used for bovine oocytes in vitro matured for 27 hours and pretreated with ionomycin ${ }^{13}$ (I). Experiments $1 \mathrm{a}$ and $1 \mathrm{~b}$ were realized in a $4 \times 3$ factorial design (4 concentrations of $\mathrm{B}$ or $\mathrm{R}$ and 3 exposure periods) with 3 additional control treatments, resulting in 15 treatments for each one.

Bohemine and roscovitine stock solutions were prepared with dimethyl-sulfoxide ${ }^{14}$ (DMSO) at a $10 \mathrm{mM}$ concentration and stored at $-20^{\circ} \mathrm{C}$. At the time of use, the stock solution was diluted to the desired concentration in modified Synthetic Oviduct Fluid [SOF supplemented with $2.5 \%$ FCS; $5 \mathrm{mg} / \mathrm{mL}$ bovine serum albumin ${ }^{15}$ (BSA) and $75 \mu \mathrm{g} / \mathrm{mL}$ kanamycin]. The final concentration of DMSO in the medium ranged from 0.5 to $1.0 \%$ depending on the treatment. For the activation treatments, the oocytes were removed from the maturation medium, washed in H199 medium (Hepes-buffered TCM-199, supplemented with $3 \mathrm{mg} / \mathrm{mL}$ BSA, $0.25 \mathrm{mM}$ sodium pyruvate and $75 \mu \mathrm{g} / \mathrm{mL}$ kanamycin) and incubated at room temperature for 5 minutes in $5 \mu \mathrm{M}$ ionomycin in H199 medium. Next, the oocytes were washed in H199 medium and in modified SOF, and randomly designated to droplets containing $0,50,75$, or $100 \mu \mathrm{M}$ of bohemine (experiment 1a) or roscovitine (experiment $1 \mathrm{~b}$ ) in modified SOF and incubated at $38.5^{\circ} \mathrm{C}$ and $5 \% \mathrm{CO}_{2}$ in air. After 2,4 or 6 hours of exposition to CDKIs, the oocytes were washed in modified SOF, transferred to CDKI-free modified SOF droplets and returned to culture, until evaluation procedures. Oocytes designated to additional control treatments were manipulated in the same way, but were not exposed to ionomycin, bohemine or roscovitine. For evaluation of pronuclear formation, 16 hours after activation treatments, the oocytes were stained with $10 \mu \mathrm{g} / \mathrm{mL}$ Hoechst $33342^{16}$ in H199 medium for 10 minutes and observed under an epifluorescence microscope. The oocytes were considered activated when one or more pronuclei were present. Treatments that showed the highest activation rates for bohemine and roscovitine were used in experiment 2.

The second experiment aimed to compare the nuclear dynamics, parthenogetic activation and blastocyst development rates promoted by ionomycin alone or followed by bohemine or 
roscovitine. Bovine oocytes in vitro matured for 24 or 27 hours were treated with ionomycin (as in experiment 1$)$ and then with bohemine $(75 \mu \mathrm{M}$ for 6 hours) or roscovitine $(50 \mu \mathrm{M}$ for 6 hours), and assessed for nuclear status, parthenogenetic activation and blastocyst development. For embryonic development, simultaneously with the activation treatment with CDKIs, the oocytes were incubated in modified SOF supplemented with $10 \mu \mathrm{g} / \mathrm{mL}$ of cytochalasin $\mathrm{B}^{17}$, to prevent polar body extrusion and induce diploid embryo development.

After the activation treatments the oocytes were transferred to modified SOF droplets and cocultured with granulosa cells. Cleavage rates were determined after 48 hours of culture and blastocyst development rates after 7 days.

In all experiments three replicates were made with 10 to 20 oocytes per treatment. The data were arc-sin transformed [(percentage square root arc-sin divided by 100 or $\left.\operatorname{arc}-\sin (\% / 100)^{1 / 2}\right)$ ] for ANOVA and interaction. Means were tested by Duncan's test at $5 \%$. Mean contrast tests between treatments were also performed at $5 \%$. To allow a better visualization of bohemine and roscovitine response to exposure time and concentration, surface response analysis were performed. The data related to nuclear status (Table 3) were performed by Fisher's exact test.

\section{RESULTS}

In experiment $1 \mathrm{a}$, a significant effect $(\mathrm{P}<0.01)$ of time was observed. Pronuclear formation increased with 6 hours $(63.4 \%$; $\mathrm{P}<0.05)$ of exposure to bohemine when compared to 2 hours $(20.9 \%)$ and 4 hours $(25.8 \%)$. For roscovitine (experiment 1b), a significant effect of exposure period $(\mathrm{P}<0.02)$ and a tendency $(\mathrm{P}<0.10)$ for an effect of the concentration employed were detected. Similarly to bohemine, pronuclear formation increased with 6 hours $(63.7 \% ; \mathrm{P}<0.05)$ of exposure to roscovitine when compared to 2 hours $(40.9 \%)$ or 4 hours $(42.2 \%)$ of exposure (Table 1$)$.

Table 1. Influence of exposure period to bohemine or roscovitine on parthenogenetic activation of bovine oocytes pretreated with ionomycin

\begin{tabular}{lcccc}
\hline & \multicolumn{2}{c}{ Bohemine } & \multicolumn{2}{c}{ Roscovitine } \\
\cline { 2 - 5 } \multicolumn{1}{c}{ Time } & $\mathrm{N}$ & Activation (\%) & $\mathrm{N}$ & Activation (\%) \\
\hline 2 hours & 92 & $20.9 \pm 5.1 \% \mathrm{a}$ & 107 & $40.9 \pm 16.6 \% \mathrm{a}$ \\
4 hours & 81 & $25.8 \pm 5.7 \% \mathrm{a}$ & 97 & $42.2 \pm 4.9 \% \mathrm{a}$ \\
6 hours & 96 & $63.4 \pm 5.4 \% \mathrm{~b}$ & 99 & $63.7 \pm 4.9 \% \mathrm{~b}$ \\
\hline
\end{tabular}

$\mathrm{N}=$ number of oocytes.

Different letters within the same column indicate a significant difference $(\mathrm{P}<0.05)$.

After 6 hours of bohemine exposure, pronuclear formation rates were $60.6 \%, 69.6 \%$ and $59.9 \%$ for 100,75 and $50 \mu \mathrm{M}$, respectively. No difference among the tested concentrations was observed $(\mathrm{P}>0.05)$. When oocytes were treated with ionomycin only $(0 \mu \mathrm{M}), 45.4 \%$ of oocytes activated. This group was not different from the others $(\mathrm{P}>0.05)$. All the groups differed $(\mathrm{P}<0.05)$ from the ionomycin-negative control $(6.3 \%)$. For 6 hours of exposure to roscovitine, pronuclear formation rates were $58.7 \%, 63.6 \%$ and $68.7 \%$ for 100,75 and $50 \mu \mathrm{M}$, respectively. No difference among the tested concentrations was observed $(\mathrm{P}>0.05)$, but when oocytes were activated with ionomycin only $(0 \mu \mathrm{M})$,
$31.4 \%$ of oocytes activated, a value significantly different $(\mathrm{P}<0.05)$ from the $50 \mu \mathrm{M}$ treatment. All groups differed $(\mathrm{P}<0.05)$ from the control $(6.2 \%)$ (Table 2). The concentrations that showed highest pronuclear formation for bohemine and roscovitine were used in the second experiment.

The surface response analysis reveled that parthenogenetic activation rates, using bohemine, are strongly dependent on exposure period to CDKI; while for roscovitine, besides exposure period, there is a less evident effect of the concentration used (Fig. 1). 


\section{Perecin et al.}

Table 2. Influence of bohemine or roscovitine concentrations $(0,50,75$ or $100 \mu \mathrm{M})$ on parthenogenetic activation of bovine oocytes pretreated with ionomycin and incubated for 6 hours in the presence of CDKIs.

\begin{tabular}{lcccc}
\hline \multirow{2}{*}{ Concentration } & \multicolumn{2}{c}{ Bohemine } & \multicolumn{2}{c}{ Roscovitine } \\
\cline { 2 - 5 } & $\mathrm{N}$ & Activation (\%) & $\mathrm{N}$ & Activation (\%) \\
\hline Control & 32 & $6.3 \pm 8.9 \mathrm{a}$ & 32 & $6.2 \pm 7.1 \mathrm{a}$ \\
$0 \mu \mathrm{M}$ & 33 & $45.4 \pm 25.0 \% \mathrm{~b}$ & 35 & $31.4 \pm 1.6 \% \mathrm{~b}$ \\
$50 \mu \mathrm{M}$ & 30 & $59.9 \pm 41.3 \% \mathrm{~b}$ & 32 & $68.8 \pm 14.0 \% \mathrm{c}$ \\
$75 \mu \mathrm{M}$ & 33 & $69.6 \pm 33.3 \% \mathrm{~b}$ & 33 & $63.6 \pm 18.2 \% \mathrm{bc}$ \\
$100 \mu \mathrm{M}$ & 33 & $60.6 \pm 29.1 \% \mathrm{~b}$ & 34 & $58.7 \pm 24.9 \% \mathrm{bc}$
\end{tabular}

$\mathrm{N}=$ number of oocytes.

Different letters within the same column indicate a significant difference $(\mathrm{P}<0.05)$.
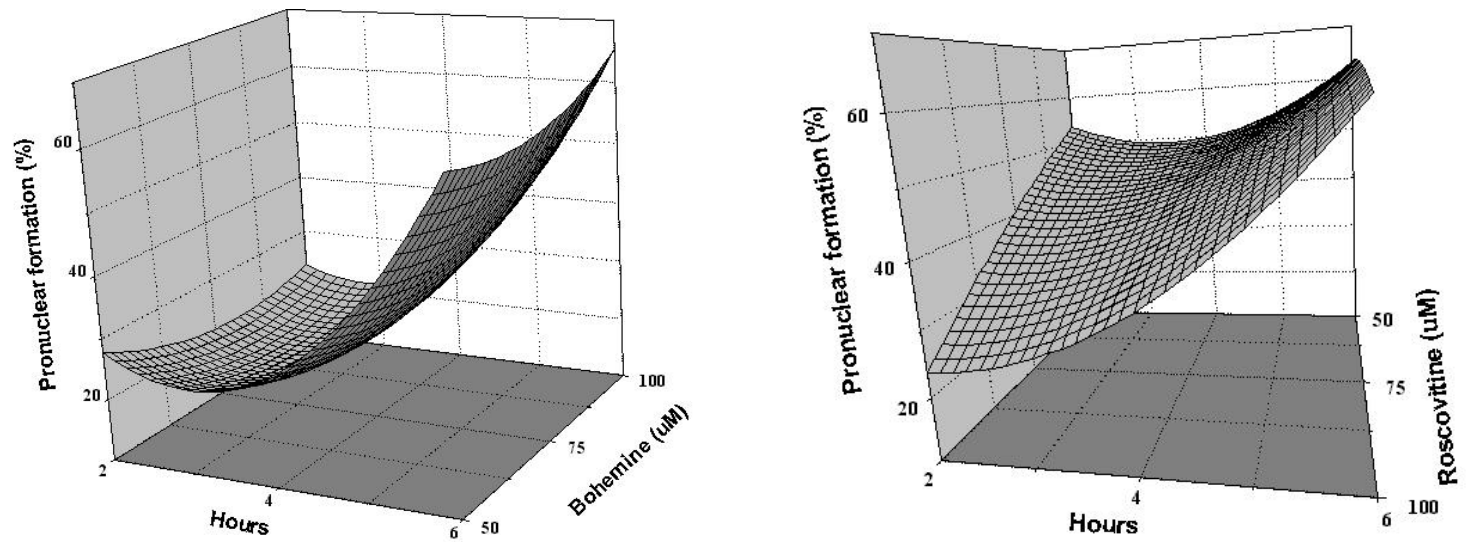

Figure 1. Bohemine and roscovitine response surface as a function of exposure period (hours) and concentration $(\mu \mathrm{M})$.

Regarding nuclear status in oocytes activated by ionomycin combined with bohemine or roscovitine, no differences were observed in polar body extrusion or pronuclear formation between the CDKIs. However, the majority of oocytes incubated for 6 hours in the presence of bohemine $(88.9 \% ; \quad \mathrm{P}<0.05)$ or roscovitine $(94.6 \% ; \mathrm{P}<0.05)$, after ionomycin treatment, showed formation of a single pronucleus and about $61 \%$ of them, showed only one polar body $(\mathrm{P}<0.05)$ (Table 3$)$. Few oocytes, ranging from 5 to $11 \%$, formed two pronuclei.

Table 3. Pronuclear formation and nuclear status of oocytes activated using bohemine or roscovitine combined with ionomycin

\begin{tabular}{lcccc} 
& \multicolumn{2}{c}{ Bohemine } & \multicolumn{2}{c}{ Roscovitine } \\
\cline { 2 - 5 } & $1 \mathrm{PN}$ & $2 \mathrm{PN}$ & $1 \mathrm{PN}$ & $2 \mathrm{PN}$ \\
\hline PB not visible & $4(6.25 \%) \mathrm{aA}$ & $2(25.0 \%) \mathrm{aA}$ & $6(8.6 \%) \mathrm{aA}$ & $3(75.0 \%) \mathrm{aA}$ \\
1PB & $40(62.5 \%) \mathrm{aB}$ & $3(37.5 \%) \mathrm{bA}$ & $42(60.0 \%) \mathrm{aB}$ & $1(25.0 \%) \mathrm{bA}$ \\
2PB & $20(31.25 \%) \mathrm{aC}$ & $3(37.5 \%) \mathrm{bA}$ & $22(31.4 \%) \mathrm{aC}$ & $0(0.0 \%) \mathrm{bA}$ \\
\hline Total & $64(88.9 \%) \mathrm{a}$ & $8(11.1 \%) \mathrm{b}$ & $70(94.6 \%) \mathrm{a}$ & $4(5.4 \%) \mathrm{b}$ \\
\hline
\end{tabular}

$\mathrm{PB}=$ polar body; $\mathrm{PN}=$ pronucleus.

Different lower-case letters within the same row indicate a significant difference $(\mathrm{P}<0.05)$.

Different upper-case letters within the same column indicate a significant difference $(\mathrm{P}<0.05)$. 
Pronuclear formation, cleavage and blastocyst development rates of oocytes activated by treatments combining ionomycin with bohemine or roscovitine showed differences from those observed in the group treated only with iomonycin, in oocytes matured for 24 or 27 hours. Pronuclear formation rates were significantly different between mean contrast of ionomycin alone versus ionomycin combined with CDKI (I x I+CDKI) in oocytes matured for 27 hours $(\mathrm{P}<0.003)$ and a statistical tendency was observed for 24 hours $(\mathrm{P}<0.08)$. For cleavage rates, the same behavior was observed for oocytes matured for 24 hours $(\mathrm{P}<0.10)$. When I and I+CDKI treatments were compared regarding blastocyst rates, a statistical tendency was observed only for oocytes matured for 27 hours $\quad(\mathrm{P}<0.08) \quad$ (Table 4). No significant differences between bohemine and roscovitine in any of the parameters evaluated were observed. The control groups showed low pronuclear formation, cleavage and blastocyst rates and differ $(\mathrm{P}<0.01)$ from the other groups.

Table 4. Pronuclear formation, cleavage and blastocyst development rates and number of oocytes $\left(\mathrm{n}_{\mathrm{o}}\right)$ or embryos $\left(\mathrm{n}_{\mathrm{e}}\right)$ evaluated for bovine oocytes in vitro matured for 24 or 27 hours and treated with ionomycin (I) or with ionomycin combined with CDKI (I+CDKI).

\begin{tabular}{lcccccc}
\hline & \multicolumn{3}{c}{24 hours } & \multicolumn{2}{c}{27 hours } \\
\cline { 2 - 7 } & $\% \mathrm{PN}\left(\mathrm{n}_{\mathrm{o}}\right)$ & $\% \mathrm{CL}\left(\mathrm{n}_{\mathrm{e}}\right)$ & $\% \mathrm{BL}\left(\mathrm{n}_{\mathrm{e}}\right)$ & $\% \mathrm{PN}\left(\mathrm{n}_{\mathrm{o}}\right)$ & $\% \operatorname{CL}\left(\mathrm{n}_{\mathrm{e}}\right)$ & $\% \mathrm{BL}\left(\mathrm{n}_{\mathrm{e}}\right)$ \\
\hline Control $^{*}$ & $5.0 \pm 5.3(46)$ & $5.7 \pm 5.5(53)$ & $0.0 \pm 0.0(53)$ & $22.1 \pm 7.8(35)$ & $20.0 \pm 15.4(40)$ & $3.0 \pm 5.1(40)$ \\
I & $42.0 \pm 23.4 \mathrm{~A}(50)$ & $21.4 \pm 0.2 \alpha(56)$ & $8.9 \pm 10.9(56)$ & $69.4 \pm 7.0 \mathrm{a}(36)$ & $48.8 \pm 26.6(41)$ & $21.9 \pm 18.3 \mathrm{~A}(41)$ \\
$\mathrm{I}+\mathrm{CDKI}$ & $47.8 \pm 18.9 \mathrm{~B}(101)$ & $27.5 \pm 11.8 \beta(109)$ & $11.8 \pm 6.0(109)$ & $77.3 \pm 5.7 \mathrm{~b}(75)$ & $70.4 \pm 23.1(84)$ & $35.2 \pm 15.6 \mathrm{~B}(84)$ \\
\hline
\end{tabular}

$\% \mathrm{PN}=$ pronuclear formation rates; $\% \mathrm{CL}=$ cleavage rates; $\% \mathrm{BL}=$ blastocyst development rates.

Different lower-case letters within the same column indicate a significant difference $(\mathrm{P}<0.003)$. Different upper-case letters $(\mathrm{P}<0.08)$ or greek-letters $(\mathrm{P}<0.10)$ within the same column indicate a statistical tendency.

* All groups differ from control $(\mathrm{P}<0.01)$.

\section{DISCUSSION}

The use of broad-spectrum inhibitors of protein synthesis or phosphorylation, such as cycloheximide or 6-DMAP, respectively, have allowed high rates of parthenogenetic activation of bovine oocytes and development to the blastocyst stage. Activation rates near $80 \%$, and 20 to $30 \%$ blastocyst development have been reported with the use of 6-DMAP (Susko-Parrish et al., 1994; Liu et al., 1998). For cycloheximide, activation rates reach $89 \%$ (Presicce and Yang, 1994) and blastocyst development reaches $40 \%$ (Liu et al., 1998). Wells et al. (1999) obtained a $27.5 \%$ blastocyst rate using 6-DMAP to activate oocytes reconstructed by nuclear transfer. However, the broad-spectrum inhibitors of protein phophorylation probably interfere with the ability of embryos and fetuses to develop normally, because different metabolic pathways may be influenced by these substances. Although high activation rates are possible with the use of 6-DMAP, chromosomal abnormalities have been observed in parthenotes (de la Fuente and King, 1998). In a similar way, it is believed that the inhibition of protein synthesis decreases not only the activity of proteins responsible for the oocyte arrest in metaphase II, but also the activity of other proteins. Moses and Kline (1995) observed abnormalities in chromosomal condensation of oocytes activated by protein synthesis inhibitors.

The mechanism involved in meiosis resumption by cyclohexemide and 6-DMAP differs from that of CDKIs. Cycloheximide prevents the formation of MPF (maturation promoting factor) molecules inhibiting cyclin synthesis (Gautier et al., 1990; Moses and Kline, 1995); while 6-DMAP inhibits phosphorylation and consequently activation of cdc25, an essential kinase for MPF activation (Lewin, 1990), but both interfere with other metabolic pathways in the cell. Bohemine and roscovitine, instead, act directly as competitive inhibitors of CDC2 (also called p34), CDK2 and CDK5 cyclin-dependent kinases, responsible for driving the cell cycle (Meijer et al., 1997). Thus, the use of specific synthetic cyclin-dependent kinases inhibitors could help to achieve activation patterns more similar to the normal fertilization process.

These results showed that meiosis resumption of metaphase II arrested bovine oocytes, as well as embryonic development to the blastocyst stage, can be increased using bohemine and roscovitine in oocytes in vitro matured for 24 or 27 hours 
and previously exposed to ionomycin. Although the highest rates of activation were obtained with $75 \mu \mathrm{M}$ of bohemine $(69.6 \%)$, the effect of bohemine on pronuclear formation is strongly dependent on the exposure time and it is not influenced by concentration, as evidenced by the response surface analysis (Fig. 1).

It was also observed that bohemine alone shows low activation efficiency, but in association with ionomycin produced promising results. Alberio et al. $(2000,2001)$ found similar results, except for activation rates, that were superior to $90 \%$. When compared to bohemine, roscovitine shows a higher capability to activate bovine oocytes without being associated to other substances and this effect increases as the concentration rises. However, as observed for bohemine, the response was low. Interestingly, when associated with ionomycin, the increase in roscovitine concentration leads to a decrease in pronuclear formation rates. The best results were found at lower concentrations, as seen in the response surface analysis (Fig. 1). Similarly to bohemine, the exposure period to roscovitine exerts a great influence in the response, but, differently from it, there is an effect of the concentration used.

There are few studies evaluating preimplantation development of embryos activated with bohemine and roscovitine in association with ionomycin. Alberio et al. (2001) observed blastocyst formation rates similar to ours $(13.3 \%$ versus $14.6 \%$, respectively) in bovine oocytes matured for 24 hours. However, in the work by Alberio et al. (2001) the embryos were obtained by nuclear transfer and activated with ionomycin+bohemine $(75 \mu \mathrm{M})$. Mitalipov et al. (2001) reported $25 \%$ of blastocyst development in Rhesus monkey oocytes parthenogenetically activated by the combination ionomycin+roscovitine.

Besides the ability to act specifically on the proteins involved with cell cycle regulation, another advantage of bohemine and roscovitine is their capability to promote a uniform activation. The majority of the oocytes submitted to CDKIs treatments developed a single pronucleus and did not extrude the second polar body.

The efficiency of specific inhibitors of cyclindependent kinases has been under investigation in the last few years and the results suggest that these drugs could be applied in cloning or ICSI programs. In vivo studies may reveal if the specific inhibitors of MPF could bring the desired effects in postimplantation development of embryos obtained by these biotechniques.

\section{CONCLUSIONS}

This study showed that in vitro matured bovine oocytes, previously exposed to ionomycin, present activation rates and preimplantation embryonic development increased by the use of bohemine and roscovitine.

\section{ACKNOWLEDGEMENTS}

To Dr. Miroslav Strnad from Palacký University, Czeck Republic, who kindly donated the bohemine.

\section{REFERENCES}

ALBERIO, R.; BRERO, A.; MOTLÍK, J. et al. Remodeling of donor nuclei, DNA-synthesis, and ploidy of bovine cumulus cell nuclear transfer embryos: effect of activation protocol. Mol. Reprod. Dev., v.59, p.371-379, 2001.

ALBERIO, R.; KUBELKA, M.; ZAKHARTCHENKO, V. et al. Activation of bovine oocytes by specific inhibition of cyclindependent kinases. Mol. Reprod. Dev., v.55, p.422-432, 2000.

CIBELLI, J.; STICE, S.L.; GOLUEKE, P.J. et al. Cloned transgenic calves produced from nonquiescent fetal fibroblasts. Science, v.280, p.1256-1258, 1998.

DE LA FUENTE, R.; KING, W.A. Developmental consequences of karyokinesis without cytokinesis during the first mitotic cell cycle of bovine parthenotes. Biol. Reprod., v.58, p.952-962, 1998.

FISSORE, R.A.; DOBRINSKY, J.R.; BALISE, J.J. et al. Patterns of intracellular $\mathrm{Ca} 2+$ concentrations in fertilized bovine eggs. Biol. Reprod., v.47, p.960-969, 1992.

GAUTIER, J.; MINSHULL, J.; LOHKA, M. et al. Cyclin is a component of maturation- 
promoting factor from Xenopus. Cell, v.60, p.487-494, 1990.

LEAL, C.L.V.; MÉO, S.C.; GARCIA, J.M. Activation of bovine oocytes by strontium combined or not with an electric pulse. Arq. Bras. Med. Vet. Zootec., v.55, p.371-373, 2003.

LEWIN, B. Driving the cell cycle: $M$ phase kinase, its partners and substrates. Cell, v.61, p.743-752, 1990.

LIU, L.; JU, J-C.; YANG, X. Parthenogenetic development and protein patterns of newly matured bovine oocytes after chemical activation. Mol. Reprod. Dev., v.49, p.298-307, 1998.

LOI, P.; LEDDA, S.; FULKA JR, J. et al. Development of parthenogenetic and cloned ovine embryos: effect of activation protocols. Biol. Reprod., v.58, p.1177-1187, 1998.

MEIJER, L.; BORGNE, A.; MULNER, O. et al. Biochemical and cellular effects of roscovitine, a potent and selective inhibitor of the cyclindependent kinases cdc2, cdk2 and cdk5. Eur. J. Biochem., v.243, p.527-536, 1997.

MÉO, S.C.; LEAL, C.L.V.; YAMAZAKI, W. et al. Influence of simple and combined ionomycin, strontium and 6-DMAP treatments on activation and parthenogenetic development. Theriogenology, v.57, p.706, 2002.

MITALIPOV, S.M.; NUSSER, K.D.; WOLF, D.P. Parthenogenetic activation of Rhesus Monkey oocytes and reconstructed embryos. Biol. Reprod., v.65, p.253-259, 2001.

MOSES, R.M.; KLINE, D. Release of mouse eggs from metaphase arrest by protein synthesis inhibition in the absence of a calcium signal or microtubule assembly. Mol. Reprod. Dev., v.41, p.264-273, 1995.

MOSES, R.M.; KLINE, D.; MASUI, Y. Maintenance of metaphase in colcemid-treated mouse eggs by distinct calcium- and 6- dimethylaminopurine (6-DMAP)-sensitive mechanisms. Dev. Biol., v.167, p.329-337, 1995.

OZIL, J.P. The parthenogenetic development of rabbit oocyte after repetitive pulsatile electrical stimulation. Development, v.109, p.117-127, 1990.

PRESICCE, G.A.; YANG, X. Parthenogenetic development of bovine oocytes matured in vitro for 24 hours and activated by ethanol and cycloheximide. Mol. Reprod. Dev., v.38, p.380385, 1994.

SOLOY, E.; KANKA, J.; VIUFF, D. et al. Time course of pronuclear deoxyribonucleic acid synthesis in parthenogenetically activated bovine oocytes. Biol. Reprod., v.57, p.27-35, 1997.

SOLTER, D. Differential imprinting and expression of maternal and paternal genomes. Annu. Rev. Genet., v. 22, p.127-146, 1988.

SUSKO-PARRISH, J.L.; LEIBFRIEDRUTLEDGE, M.L.; NORTHEY, D.L. et al. Inhibition of protein kinases after an induced calcium transient causes transition of bovine oocytes to embryonic cycles without meiotic completion. Dev. Biol., v.166, p.729-739, 1994.

SUTTNER, R.; ZAKHARTCHENKO, V.; STOJKOVIC, P. et al. Intracytoplasmic sperm injection in bovine: effects of oocyte activation, sperm pretreatment and injection technique. Theriogenology, v.54, p.935-948, 2000.

TALMOR-COHEN, A.; ELIYAHU, E.; SHALGI, R. Signalling in mammalian egg activation: role of protein kinases. Mol. Cell. Endocrinol., v.187, p.145-149, 2002.

WAKAYAMA, T.; PERRY, A.C.; ZUCCOTTI, $M$. et al. Full-term development of mice from enucleated oocytes injected with cumulus cell nuclei. Nature, v.394, p.369-374, 1998.

WELLS, D.N.; MISICA, P.M.; TERVIT, H.R. Production of cloned calves following nuclear transfer with cultured adult mural granulosa cells. Biol. Reprod., v.60, p.996-1005, 1999. 